\title{
Assessment of Various Sterilants on Differential Growth Response in Carica papaya
}

\author{
Nisha Malik ${ }^{1 *}$, Rakesh Singh Sengar ${ }^{1}$, Devendra Kumar ${ }^{1}$, Shiv Kumar Singh ${ }^{2}$, \\ Manoj Kumar Yadav ${ }^{1}$, Mukesh Kumar ${ }^{3}$ and Gopal Singh ${ }^{4}$
}

${ }^{1}$ Department of Agricultural Biotechnology, College of Agriculture, Sardar Vallabhbhai Patel University of Agriculture and Technology, Meerut -250110 (U.P.), India

${ }^{2}$ Department of Genetics and Plant Breeding, College of Agriculture, Sardar Vallabhbhai Patel University of Agriculture and Technology, Meerut -250110 (U.P.), India

${ }^{3}$ College of Horticulture, Sardar Vallabhbhai Patel University of Agriculture and Technology, Meerut -250110 (U.P.), India

${ }^{4}$ Department of Plant Pathology, College of Agriculture, Sardar Vallabhbhai Patel University of Agriculture and Technology, Meerut -250110 (U.P.), India

*Corresponding author

Keywords

Sterilant,

Contamination,

Papaya, Survival

Article Info

Accepted:

25 January 2019

Available Online:

10 February 2020
Papaya is a nutraceutical fruit crop grown among tropical and sub-tropical regions of the world. The propagation through seeds results in the production of non-true-type planting materials due to segregation of offsprings at second filial generation leading to inherent heterozygosity. The alternative strategy to this is in-vitro propagation, but the main hurdles comes under this method is failure to culture establishment. Thus, searching for an effective sterilization is always needed. Therefore, present study was intended to evaluate the effect of various sterilant on culture establishment. The lateral buds were collected as explant and treated with $0.1 \%$ Bavistin, $0.1 \% \mathrm{HgCl}_{2}, 4 \% \mathrm{NaOCl}$ and $70 \% \mathrm{EtOH}$ for different time interval. The higher survival percent and uniform growth pattern was observed with $0.1 \%$ Bavistin for $10 \mathrm{~min}(38.7), 0.1 \% \mathrm{HgCl}_{2}$ for $2 \min (40.5), 4 \% \mathrm{NaOCl}$ (39) and $70 \% \mathrm{EtOH}$ for $1 \mathrm{~min}$ (37.8), whereas combination of these sterilant showed $46.3 \%$ shoot survival with uniform growth.

\section{Introduction}

Papaya is a nutraceutical important fruit crop grown over tropical and sub-tropical region of the world (Jaime et al., 2007; Ryavalad et al., 2019). In India, papaya represented by four species in which Carica ppaya L. is the most widely cultivated and the best known species 
(Jean et al., 2011; Vij and Prashar, 2015). This crop is cultivated over 71 countries of the world, and India apart its major part in respect to the area (13400 ha), yield (443284 hg/ha) and production (5940000 tonnes) (FAOSTAT, 2017). At conventional scale, it is propagated through seeds (Fernando et al., 2001), but the set back of seed propagation is the production of nontrue-to-type planting materials (Panjaitan et al., 2007; Tsai et al., 2009) due to segregation of off-springs at second filial generation that leads to inherent heterozygosity (Veerannale, 1984; Rajeevan and Pandey, 1986) andhigh percentages of unwanted male plants (Farzana et al., 2008).

Papaya plants can also be grown via asexual means (cutting and grafting) but these methods are very tedious and impractical when carried out at large scale (Saker et al., 1999). Moreover, these methods cannot be used to prevent transmission of systemic disease from mother plants (Van-Hong et al., 2018). Now days, tissue culture techniques had witnessed as an efficient technique for the multiplication of specified sex type plants, production of true-to-type, disease-free plantlets and in the genetic transformation studies. The foremost obstacle emanates to invitro propagation is failure to culture establishment due to microbial contamination by surface and endogenous microbes when explants collected from mature field grown plants (Wu et al., 2012; Kumar et al., 2019).

The collected explants from field conditions comprehends huge number of microbes on their surface. During in-vitro propagation, fiasco in ample exclusion of these contaminants affects explant/ shoot sustenance and strive with inoculated explant for sustenance (Kumar et al., 2019). Contagious contaminations diminish the impermanence of in-vitro cultures and cause necrosis. The explant inoculated on medium skipping any sterilant treatment consequences in a reduced amount of culture sustenance, sometimes no culture survival. The pervasiveness of uncleanness makes culture establishment vulnerable in accomplishing goal line. The effectiveness of in-vitro culture establishment needs preliminary consideration to explant assortment following an effective treatment of sterilizing agents.

The assortment of sterilizing agents should be the kind which could eliminate wide range of contamination (Panhwar, 2005), and confirm higher culture subsistence. The successfulness of sterilization protocol is the key point to circumvent the incursion and growth of contaminants. Thus, better optimization of sterilant combination is always needed to accomplish sustainable micropropagation. Therefore, study was intended to assess the various sterilant and their combination on explant survival and shoot growth using lateral bud as explant.

\section{Materials and Methods}

The current study was conducted at Tissue culture laboratory, Department of Agricultural Biotechnology, College of Agriculture, SVPUA\&T, Meerut. The explant for current study were collected from field grown mature papaya plants in the form of lateral buds (Fig. 1). The propagation medium was prepared by augmenting with $30 \mathrm{~g} / \mathrm{L}$ sucrose, $100 \mathrm{mg} / \mathrm{L}$ polyvinyl pyrrolidone, $100 \mathrm{mg} / \mathrm{L}$ myo-inositol and agar $(8 \mathrm{~g} / \mathrm{L})$. The media $\mathrm{pH}$ was adjusted to 5.8 and autoclaved at $121^{\circ} \mathrm{C}(101 \mathrm{kpa})$ for 15 minutes. The media was poured in presterilized culture tubes $(150 \times 25 \mathrm{~mm})$ and incubated in culture room. The media was visualized for any contaminant growth after 3 days.

\section{Explant collection and initial treatment}

The procured lateral buds were collected in a jam bottle filled with autoclaved de-ionized water and washed till complete removal of glue-like white discharge. The explants were incubated in $0.5 \% \quad \mathrm{Ca}(\mathrm{OCl})_{2}$ solution 
containing two to three drops of each Triton$\mathrm{X}$ and Tween 20 (Hi-Media). After $30 \mathrm{~min}$, washing was carried with autoclaved deionized water till complete amputation of detergent traces. The explants were transferred in $0.1 \%$ polyvinyl pyrrolidone (PVP) solution till further sterilant treatment(Fig 2a).

\section{Sterilant treatment and explant preparation}

The explants were treated with various sterilants for different time intervals viz. $0.01 \%$ Bavistin $^{\mathrm{TM}}(5,10,15$ and $20 \mathrm{~min})$, $0.1 \%$ Mercuric chloride (1, 2, 3 and $4 \mathrm{~min}$ ), $4 \%$ Sodium hypochlorite $(5,10,15$ and 20 min) and $70 \%$ Ethanol (Table 1). Explants were washed three times with autoclaved deionized water (Fig. 2b). Finally, explants were excised in aseptic manner minimizing any damage to the apical part of bud with the help of needed point forceps and scalpel blade in $0.5 \mathrm{~cm}$ diameter (Fig 2c). The prepared explants were carefully inoculated on medium(Fig 2d) without touching the walls of culture tube and incubated under 1500 lux white fluorescent light. The growth room conditions were maintained at $16 \mathrm{~h}$ of light and $8 \mathrm{~h}$ of dark photoperiod, 50-60\% RH and $25 \pm 2^{\circ} \mathrm{C}$ temperature.

\section{Statistical analysis}

The culture progress was visualized at regular interval of 3 days for contaminant growth for four weeks and data was noted for contaminated, survived and culture growth pattern. Culture survival percent was calculated as per the formula discussed by Kumar et al., (2019). ANOVA was performed and represented as mean $\pm \mathrm{SE}$, and significant difference was determined at probability level of $5 \%$.

\section{Results and Discussion}

The success of in-vitro culture subsistence is the dependent of explant choice and its source following their sterilization procedures. The filed based explant sources face countless contaminants on its exterior. In-vitro propagation of papaya is difficult due to various problems such as: microbial contamination by endogenous bacteria particularly, when field grown plants are used for explant source (Al-Shara et al., 2018; Wu et al., 2012). Moreover, culture media used for in-vitro propagation is the most appropriate for contaminants development thus, complete extrusion or surface disinfection of procured explant is much imperative (Kumar et al., 2019). Under present study, we also faced similar difficulties while cultured lateral buds. Therefore, different sterilant for varying durations had been optimized for higher culture survival.

Under study, the observations noted are given in Table 1and Fig 3. The control (no sterilant) was observed with no shoot or zero explant survival. Bavistin ${ }^{\mathrm{TM}}$ is a widely used fungicide as sterilant in plant tissue culture studies (Khatun et al., 2016). The higher explant survival percent $(38.7 \pm 0.02)$ with healthy and uniform growth was noted when explant treated with Bavistin for $10 \mathrm{~min}$ as compared to other time durations. Whereas, Bavistin treatment for 20 min resulted in least survival percent and non-uniform shoot growth. The findings under study are in harmony with Kumar et al., (2019).

Mercuric chloride $\left(\mathrm{HgCl}_{2}\right)$ is the chemical compound that is used as disinfectant (Anburaj et al., 2011). Under study, explants treated with $0.1 \% \mathrm{HgCl}_{2}$ for 2 min were found to be healthy and uniform with maximal subsistence percent $(40.5 \pm 0.9)$. The explant treated till 4 min with $\mathrm{HgCl}_{2}$ showed in tissue necrosis. The results observed under study had supported by the study of Rayavalad et al., (2019), whereas Roy et al., (2012) described 
$\mathrm{HgCl}_{2}$ treatment for $8 \mathrm{~min}$ and Bindu and Podikunju (2017) conveyed $0.08 \% \quad \mathrm{HgCl}_{2}$ treatment for 12 min while using lateral buds of papaya. Kumar et al., (2019) also reported optimized explant survival with $0.1 \% \mathrm{HgCl}_{2}$ for $5 \mathrm{~min}$ for sugarcane apical shoot meristem. It was noted that increase in treatment duration was led to tissue necrosis and growth was impaired. The bleaching action of two chloride ions that associate strongly with proteins cause tissue necrosis.

Table.1 Effect of sterilants on explant survival and growth pattern

\begin{tabular}{|c|c|c|c|c|}
\hline $\begin{array}{c}\text { Sterilant } \\
\operatorname{Conc}^{\mathrm{n}}(\%)\end{array}$ & Time (min) & Survival \% & CV\% & Characteristics of shoots \\
\hline Control & & NIL & 0 & Contaminated \\
\hline \multirow[t]{4}{*}{ Bavistin $(0.1 \%)$} & 5 & $35.3 \pm 1.3$ & 0.04 & Uniform \\
\hline & 10 & $38.7 \pm 0.0$ & 0.02 & Healthy and uniform \\
\hline & 15 & $33.8 \pm 1.3$ & 0.04 & Uniform \\
\hline & 20 & $27.0 \pm 1.1$ & 0.04 & Non- uniform and unhealthy \\
\hline \multirow{4}{*}{$\begin{array}{c}\text { Mercuric } \\
\text { Chloride } \\
(0.1 \%)\end{array}$} & 1 & $37.0 \pm 1.8$ & 0.05 & Uniform \\
\hline & 2 & $40.5 \pm 0.9$ & 0.02 & Healthy and uniform \\
\hline & 3 & $26.0 \pm 1.3$ & 0.05 & Non-uniform \\
\hline & 4 & $17.7 \pm 1.9$ & 0.11 & No shoot induction (Tissue necrosis) \\
\hline \multirow{4}{*}{$\begin{array}{c}\text { Sodium } \\
\text { Hypochlorite } \\
(4 \%)\end{array}$} & 5 & $39 \pm 0.7$ & 0.02 & Healthy and uniform \\
\hline & 10 & $35.2 \pm 1.2$ & 0.03 & Uniform \\
\hline & 15 & $33.7 \pm 1.7$ & 0.05 & Medium and Uniform \\
\hline & 20 & $25.3 \pm 1.7$ & 0.07 & Uniform \\
\hline \multirow{4}{*}{$\begin{array}{c}\text { Ethanol } \\
(70 \%)\end{array}$} & 1 & $37.8 \pm 0.6$ & 0.02 & Healthy but non-uniform \\
\hline & 2 & $34.2 \pm 0.9$ & 0.03 & Uniform \\
\hline & 3 & $32.0 \pm 1.4$ & 0.04 & Uniform \\
\hline & 4 & $29.2 \pm 1.2$ & 0.04 & Uniform \\
\hline $\begin{array}{c}\text { Combination } \\
{[\text { Bavistin }(0.1 \%)} \\
+\mathrm{HgCl}_{2}(0.1 \%) \\
+\mathrm{NaOCl}(4 \%)+ \\
\text { EtOH }(70 \%)]\end{array}$ & $\begin{array}{l}(10+2+5+ \\
\text { 1) followed by } \\
\text { three times } \\
\text { washing after } \\
\text { each sterilant } \\
\text { treatment }\end{array}$ & $46.3 \pm 1.5$ & 0.03 & Healthy and uniform \\
\hline
\end{tabular}


Fig.1 Explant collection from field

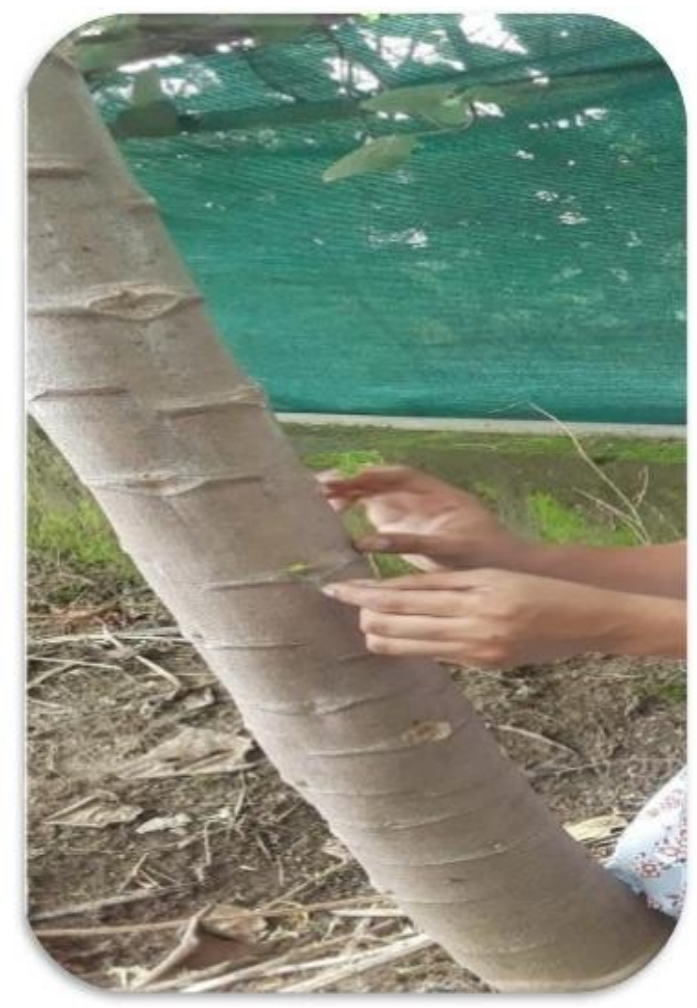

Fig.2 Explant sterilization; Explant pretreatment (incubation in $\mathrm{Ca}(\mathrm{OCl})_{2}+$ Triton-X + Tween 20 a), Sterilant treatment and washing b), Explant preparation c), Explant inoculation d)

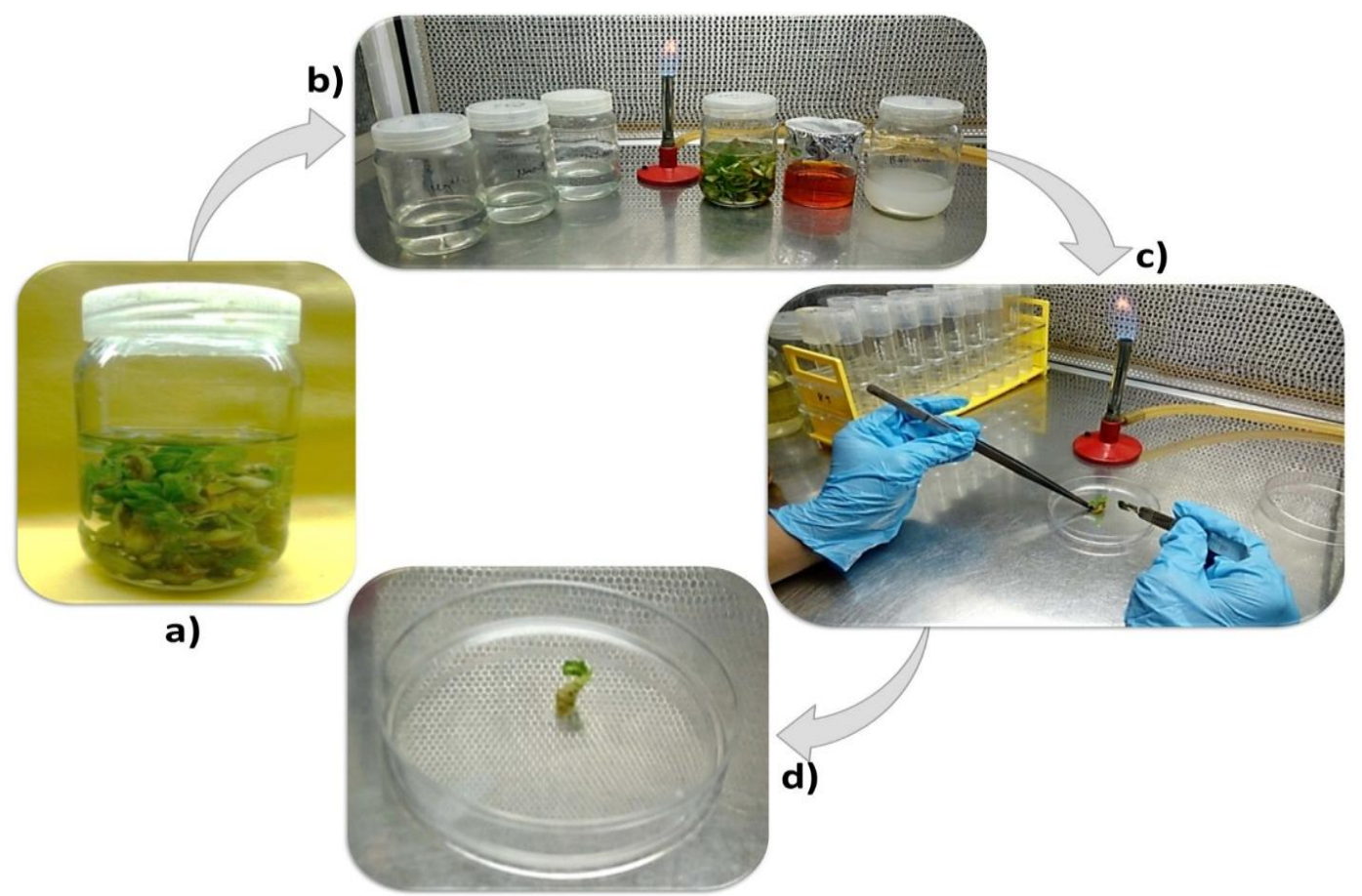


Fig.3 Observations for shoot survival

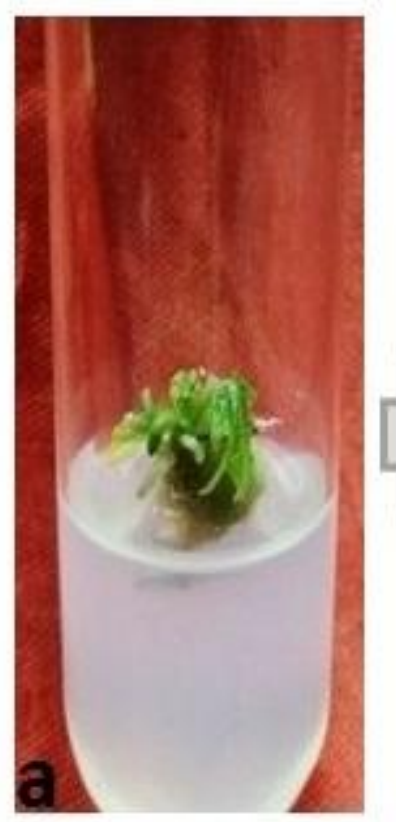

Sodium hypochlorite $(\mathrm{NaOCl})$ is an effectively used sterilant in micropropagation studies (Kumar et al., 2019). Under study, the subsistence proportion with $4 \% \mathrm{NaOCl}$ ranged $25.3 \pm 1.7(20 \mathrm{~min})$ to $39 \pm 0.73(5 \mathrm{~min})$. Reda et al., (2004) also considered $\mathrm{NaOCl}$ as a potent sterilizing agent for explant surface sterilization.

Ethanol (EtOH) has higher bactericidal action in comparison to other surfactants (Bloomfield, 1978). However, in present study $\mathrm{EtOH}$ was not found so much effective as other sterilants, as it showed non-uniform shoot growth. Higher culture survival percent with healthy and uniform shoot growth (37.8 \pm 0.6$)$ as compared to other treatments was observed in explants treated with $70 \%$ $\mathrm{EtOH}$ for $1 \mathrm{~min}$. Our study reports were found in agreement to the study done by Roy et al., (2012).

Under study, the highest shoot survival (46.3 \pm 1.5) with optimum shoot growth (Fig. 3) was observed when explants treated in combination by following three washings

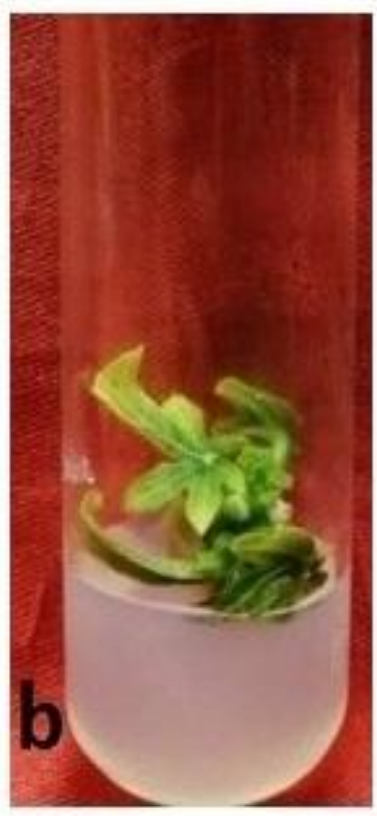

with autoclaved de-ionized water after each sterilant treatment. Kumar et al., (2019) also described satisfactory explant sterilization using sterilant combination.

It is concluded under study, lesser treatment duration was showed with higher culture survival but at same time it was not effective to completely removal of bacterial infection. However, increasing duration resulted in tissue necrosis. The satisfactory observations were recorded when explants treated with the sterilant combination.

\section{Acknowledgments}

Author acknowledges the Vice Chancellor and HOD, Agricultural Biotechnology, SVPUA\&T, Meerut (U.P.) for providing all necessary facilities to carry out thisexperiment.

\section{References}

Anburaj, J., Singh C.R., Kuberan, T., Sundaravadivelan, C. and Kumar, P. 
2011. Effects of plant growth regulators on callus induction from leaf explants of Cleome viscose. Res. J. Pharm. Biol. Chem. Sci. 2: 576.

Bindu, B. and Podikunju, B. 2017. Tissue Culture Protocol for In-vitro Propagation of Papaya (Carica papaya L.). J. Krishi Vigyan 6(1): 205-212.

Bloomfield, S.F. 1978. A review: The use of disinfectants in the home. J. Appl. Bacteriol. 4(1): 38 .

FAOSTAT 2017. Statistical division: production domain- Crops. Food and Agriculture Organization of the Unite Nations: FAO Statistical Databases. http://faostat.fao.org. Accessed date 06 Dec 2019.

Farzana, A.R.F., Palkadapala, P.G.V.N., Meddegoda, K.M.M.N., Samarajeewa, P.K. and Eeswara, J.P. 2008. Somatic embryogenesis in papaya (Carica papaya L. cv. Rathna). J. Natn. Sci. Foundation Sri Lanka 36(1):41-50.

Fernando, J.A., Melo, M. and Soares, M.K.M. 2001. Anatomy of somatic embryogenesis in Carica papaya L. Braz. Arch. Biol. Technol. 44: 247-255.

Jaime, A., Silva, T.D., Rashid, Z., Nhut, D.T., Sivakumar, D., Gera, A., Souza, M.T. and Tennant, P.F. 2007. Papaya (Carica papaya L.) Biology and Biotechnology. Tree and forestry Sci. Biotech. 1(1): 4773.

Jean, J., Soucy, J. and Pouliot, R. 2011. Effects of retinoic acid on keratinocyte proliferation and differentiation in a psoriatic skin model. Tissue Eng. Part. A. 17: 1859-1868.

Khatun, M.M., Tanny, T., Razzak, A.M., Alam, M.F., Uddin, M.E., Amin. R. and Yesmin, S. 2016. Standardization of in vitro sterilization procedures for micropropagation of Ginger (Zingiber officinale Rosc.). Int. J. App. Biol. Pharma. Technol. 7: 1.

Kumar, D., Sengar, R.S., Yadav, M.K.,
Chand, P., Singh, G. and Gupta, S. 2019. Evaluation of sterilant effect on in-vitro culture establishment in sugarcane variety Co 0118. Int. J. Curr. Microbiol. App. Sci. 8(07): 1226-1233. doi: https://doi.org/10.20546/ijcmas. 2019.807.146

Panhwar. F. 2005. Acclimatization and establishment of micropropagation plants. By DigitalVerlag Gmbh, Germany. p. 1-8.

Al-Shara, B., Taha, R.M. and Rashid,K. 2018. Biotechnological methods and limitations of micropropagation in papaya (Carica Papaya L.) production: A Review. The J. Anim. Plant Sci. 28(5): 1208-1226.

Panjaitan, S.B., Aziz, M.A., Rashid, A.A. and Saleh, N.M. 2007. In-vitro plantlet regeneration from shoot tip of fieldgrown hermaphrodite papaya (Carica papaya L. cv. Eksotika). Int. J. Agril. Biol. 6: 827-832.

Rajeevan, M.S., Pandey, R.M. 1986. Lateral bud culture of papaya (Carica papaya L.) for clonal propagation. Plant Cell Tiss. Org. Cult. 5: 181-188.

Reda, E.A., Moghaieb, S.H. and Fujita, K. 2004. Shoot regeneration from GUStransformed tomato (Lycopersicon esculentum) hairy root. Cellular and Mol. Biol. Letters 9: 439-449.

Roy, P.K., Roy, S.K. and Hakim, MD.L. 2012. Propagation of papaya (carica papaya 1.) cv. shahi through in-vitro culture. Bangladesh J. Bot.41(2): 191195.

Ryavalad, S., Malabasari, T.A., Shantappa, T., Uppar, D.S., Biradar, B.D. and Mantur, S.M. 2019. Micropropagation Studies in Papaya (Carica papaya L.) cv. 'Surya'. Int. J. Curr. Microbiol. Appl. Sci. 8(4): 2362-2367.

Saker, M.M., Bekheet, S.A., Taha, H.S. and Reda, A.A. 1999. In vitro propagation of papaya (Carica papaya L.). Sci. 
Biotechnol. 1: 47-53.

Tsai, S.F., Yeh, S.D., Chan, C.F. and Liaw, S.L. 2009. High efficiency vitrification protocols for cryopreservation of in vitro grown shoot tips of transgenic papaya lines. Plant Cell Tiss. Org. Cult. 98: 157-164.

Van-Hong, N., Chung-Ruey, Y. and ChingHsiang, H. 2018. Effect of nutritional and growth hormonal factors on in vitro regeneration of papaya (Carica Papaya L. Cv. Red Lady). J. Natn. Sci. Foundation Sri Lanka 46 (4):559-568.
Veerannale, L. 1984. Seasonal Rytham on the Sex Expression of Papaya. In: Proc. Natl., Seminar Papaya and Papain Production. Tamil Nadu Agric. Univ. Coimbatore, Madras, p.1-3.

Vij, T. and Prashar, Y. 2015. A review on medicinal properties of Carica papaya Linn. Asian Pac. J. Trop. Dis. 5(1): 1-6.

Wu, K., Zeng, S., Chen, Z. and Duan, J. 2012. In-vitro mass propagation of hermaphroditic Carica papayacv. Meizhonghong. Pak. J. Bot. 44(5): 1669-1676.

\section{How to cite this article:}

Nisha Malik, Rakesh Singh Sengar, Devendra Kumar, Shiv Kumar Singh, Manoj Kumar Yadav, Mukesh Kumar and Gopal Singh. 2020. Assessment of Various Sterilants on Differential Growth Response in Carica papaya. Int.J.Curr.Microbiol.App.Sci. 9(02): 30803087. doi: https://doi.org/10.20546/ijcmas.2020.902.355 